\title{
Extração de dados de biomassa disponível dos resíduos sólidos urbanos da Região Administrativa de Campinas.
}

\section{Ricardo M. M. Aguiar*, Telma T. Franco}

\section{Resumo}

Há uma enorme quantidade de matéria prima disponível na forma de resíduos no Brasil, a qual pode potencialmente ser utilizada para geração de energia e obtenção de produtos químicos. Neste projeto utilizamos dados da Região Administrativa de Campinas (RAC) referentes a resíduos sólidos urbanos (RSU) e demanda populacional dos centros urbanos/ indústrias sucroalcooleiras (SUC). As informações foram armazenadas no software ArcGis e analisadas. Além disso, foi estimado o potencial de conversão do RSU em bioetanol.

\section{Palavras-chave}

energia, resíduos sólidos urbanos, potencial.

\section{Introdução}

A RAC é composta por 92 cidades, aglutinando 6 milhões de habitantes. Os dados coletados foram armazenados no software ArcGis com o intuito de analisá-los mais facilmente. Foram localizados clusters, regiões aonde, por exemplo, pode-se estabelecer a ligação entre um aterro, com sua biomassa disponível, e uma SUC, interessada nessa matériaprima. Também foi calculado o potencial de produção de bioetanol a partir do RSU dos aterros da RAC.

\section{Resultados e Discussão}

Segue um exemplo de um cenário montado:

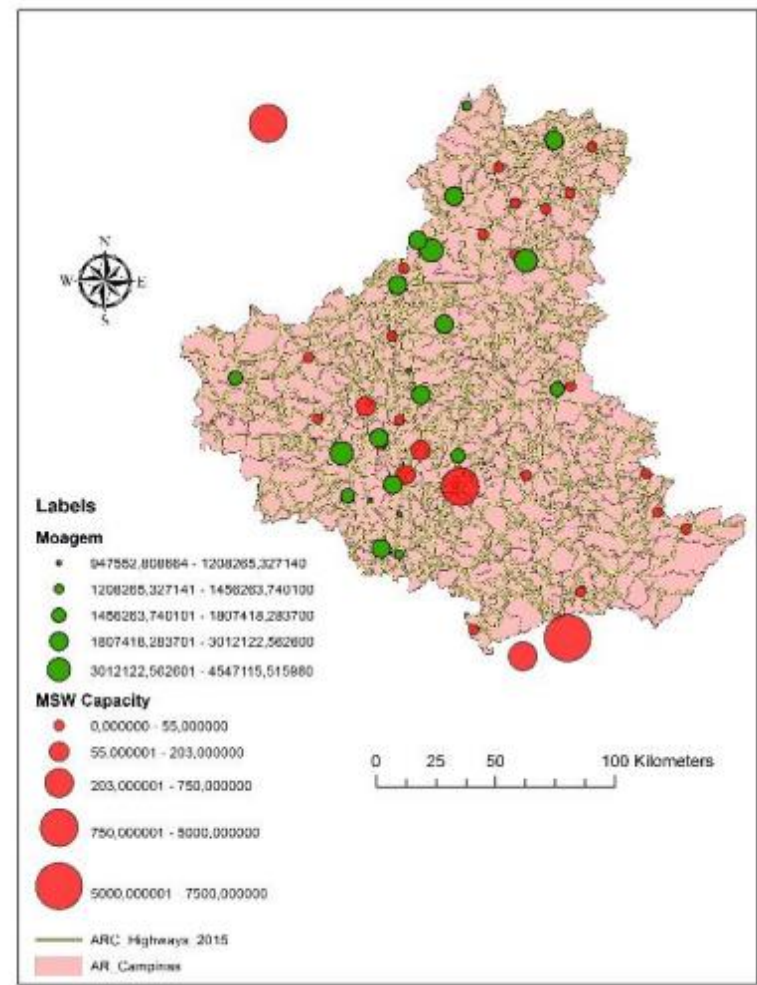

Figura 1: Localização dos RSU e SUC

As SUC estão representadas pelos círculos verdes e os aterros pelos círculos vermelhos, de acordo com o potencial de produção de etanol e de resíduo, respectivamente. Além disso, está disposta a malha rodoviária em amarelo do RAC. Assim como esse exemplo, podem ser feitas inúmeras combinações de dados com o software ArcGis levando a cenários reais, onde sejam propícias as condições de transporte, demanda e oferta de energia e de resíduos.

A Figura 2 compara a produção de etanol de 4 SUCs regionais e o potencial do aterro de Paulínia:

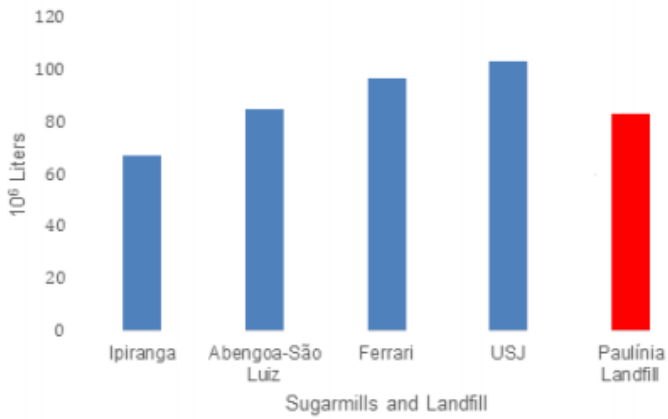

Figura 2: Produção de etanol de 4 SUC

O aterro de Paulínia possui o maior potencial de produção de bioetanol da RAC.

\section{Conclusões}

Percebe-se que o potencial de produção de bioetanol do aterro de Paulínia equipara-se ao de algumas usinas do RAC, sugerindo que estudo de viabilidade técnicoeconômica deve ser continuado.

\section{Agradecimentos}

Agradeço às instituições NIPE-Unicamp e ao Pibic, assim como todos pesquisadores e alunos que ajudaram nas pesquisas.

(CETESB). Inventário Estadual de Resíduos Sólidos Urbanos, 2014. Disponível em: < http://residuossolidos.cetesb.sp.gov.br/wpcontent/uploads /sites/36/2013/11/residuosS olidos2014.pdf >. Acesso em: out. 2015.

(CTBE); CNPEM. 2011 Report: The Virtual Sugarcane Biorefinery (VSB). Disponível em . Acesso em nov. 2015 